\title{
Bernard Shaw's Ibsenisms
}

Javier Ortiz

State University of New York at Binghamton

\begin{abstract}
This paper deals with the complex and ambiguous admiration that Bernard Shaw professed for the Scandinavian playwright Henrik Ibsen. Throughout Shaw's professional life as a critic, he devoted a great deal of his writings to analyze and decipher Ibsen's plays for British audiences. Shaw wrote three sets of critical essays on Ibsen: The Quintessence of Ibsenism, Our Theatres in the Nineties, and The Prefaces. The article emphasizes not only the evolution in Shaw's Ibsen criticism, but also the parallelism of that evolution with the confirmation of Shaw himself as a world renown playwright. In The Quintessence Shaw discusses Ibsen's plays superficially, since he himself was in the process of becoming a playwright of the sort of Ibsen. In Our Theatres Shaw orientates his criticism around the plays themselves-he does not need to hide Ibsen's achievements from the British audience any more, as he already claims to master drama creation as much as Ibsen did in his time. Finally, in The Prefaces the critic shows many reservations towards Ibsen's dramaturgy becoming the ultimate estimations of Shaw's Ibsen interpretations.
\end{abstract}

Traditionally, Henrik Ibsen's influence in Bernard Shaw has been framed almost exclusively in what the British critic and playwright discussed in The Quintessence of Ibsenism. Although this can be taken as partially true, we must add some considerations about Ibsen, and more specifically, about Shaw's interpretations of such an Ibsenism. Therefore, the goal of this essay is going to have a double scope. On the one hand, the analysis of how their contemporaries perceived Shaw's interpretations of Ibsenism will occupy the first stage. On the other one, it is essential to specify and clarify how Shaw developed his interpretation of Ibsenism, expressed not only in the Quintessence, but also in other pieces of criticism, and in most of his plays. In order to determine whether Shaw misunderstood and misinterpreted Ibsen, an author for whom he professed the greatest admiration, it is necessary to examine all his Ibsen criticism. It is true that Shaw was a novelist, journalist, critic, and dramatist; therefore, considering in which of these capacities he wrote about Ibsen is essential. 
On many occasions, Shaw tried to persuade his readers of what he considered a false and superficial influence of Ibsen in his plays. But he never went as far as when he said: "What! I a follower of Ibsen! My good sir, as far as England is concerned, Ibsen is a follower of mine!" (Quintessence 25). This remark was made by Shaw in the first edition of the Quintessence, and it is characteristic of his treatment of the subject. Shaw frequently denied that he was influenced by Ibsen. Nevertheless, the similarities are so obvious in some cases, that a reconsideration of them is not worth it. The starting point of the essay is based on the assumption that Shaw was in debt with the Scandinavian playwright.

It has been widely accepted that Edmund Gosse introduced Ibsen to England, William Archer translated his plays, but it was Shaw who became the authentic exponent of Ibsen's message to the British public. Shaw started writing about Ibsen with the Quintessence of Ibsenism in 1891, and then he enlarged it in 1913. As early as 1890, Shaw made his first public mistake about Ibsen by calling him a "socialist" (Wisenthal 77) in a Fabian exposition. From that moment, some writers and critics (such as Archer, Archibald Henderson, Frank Harris, and Henry Arthur Jones) sprung to defend Ibsen from "Mr. Bernard Shaw's victimization of him" (Franc 34). The Quintessence of Ibsenism, which was Shaw's revision in book form of his original Fabian exposition of Ibsen, became the standard exponent of misguided Ibsen criticism. Even William Archer, one of Shaw's closest friends, warned against such misinterpretations: “A grave injustice has been Ibsen of late by those of his English admirers who have set him up as a social prophet, and sometimes omitted to mention that he was a bit of a poet as well" (Franc 35). Archer's point is crucial in the development of the discussion, but not as much as the commonly asserted affirmation that Shaw, rather than talking about Ibsen, is talking about himself in his criticism. Evidently, all these accusations were refuted by Shaw in two other sets of his critical work (Out Theatres in the Nineties and Prefaces).

In The Quintessence Shaw was writing as a socialist novelist and a playwright-to-be. In Our Theatres of the Nineties, from 1895 to 1898, he continued in the form of weekly criticism contributed to the Sunday Review, where Shaw was working as a professional play reviewer and dramatist. Finally, from the beginning of the century to 1930, a world renown Shaw wrote about Ibsen in The Prefaces to some more modern plays. These three phases, sometimes overlapped one to another, must be viewed as the more or less conscious process that Shaw intended to achieve when examining Ibsen's plays.

At this point, before proceeding to the main body of Shaw's criticism, we should distinguish one of Shaw's beliefs from Ibsen's attitude. Despite all the bad aspects of our era many people are convinced that humanity has improved over the centuries in terms of ethic, government and law. There is a common assumption that we should be happier than our predecessors. As far as Ibsen was concerned, on the contrary, 19th century in Norway was not better than, for example, the 9th century, the age of the Vikings. All that mattered fundamentally to Ibsen was the noble spirit which flickered here and there in every generation, and just a small number behaved in accordance with nature.

Shaw's point of view is different. On the one hand he claims that there must be improvement in mankind, but on the other hand, as he explains through Tanner in one of the sections of the Revolutionists Handbook in Man and Superman, "we must frankly give up the notion that man as he exists is capable of net progress" (Man and Superman 421). 
That was written in 1903, but as late as 1944, in Everybody's Political What Is What, he answers his own question by saying that some cure will eventually work.

So, there was from the beginning a remarkable difference between Shaw and Ibsen, but in The Quintessence this difference is disguised. Towards the end of the essay, Shaw says that Ibsen is not looking for a golden rule which conducts life; in his own words, Shaw is saying to his readers about Ibsenism that "its quintessence is that there is no formula" (Quintessence 125). Thus, the difference noted above can be transcended to a higher degree; we are talking about a world of difference between an Ibsen who refused to narrow structures into ideas, and a Shaw who could hardly refrain himself from doing so. Ibsen discouraged exactly what Shaw demanded: the drawing of general conclusions from particular fictional instances.

Partly because of its origins in a paper Shaw read to the Fabian Society in 1890, The Quintessence of Ibsenism is a mixture of adequate exposition and progressist misinterpretation. In the first section of the essay, Shaw advances the thesis that in his works, Ibsen is attacking false ideals in other 19th-century writers or in other social contexts with slight relation to Ibsen.

From the very beginning Shaw states that his purpose is "to distill the quintessence of Ibsen's message to his age" (Quintessence 15). However, he insists that the value of Ibsen's plays lies in their message, and discusses them as if they were novels, without any attention to their dramatic form. Certainly these are strange and naive misinterpretations, but why does Shaw insist on the message of the plays ignoring completely the most basic kind of dramatic concerns? To answer that question it has to be pointed out that Shaw published The Quintessence for a very specific public, and that only the newspaper controversy launched by Ghosts in 1891 led him to write in the form of essay his Fabian Lecture. With these premises, we can affirm that Shaw's purpose with the publication of The Quintessence was both polemic and ambiguous. Polemic, because he was writing at the outset of the virulent controversy which raged England for five years. Ambiguous, because Shaw placed special emphasis on reading, rather than seeing Ibsen's plays.

Shaw was trying to take advantage of the creation of a new audience through the reactivation of the old habit among the British of the reading of plays. This audience was predisposed to new ideas and new methods in drama, and it was this new public which made possible Ibsen's great success with British readers, even though he never was completely victorious on the English stage.

It is at this point where, in my opinion, Shaw's main success in The Quintessence lies. He intended to make Ibsen interesting to novel readers; his summaries in novelistic form had the mere goal of deciphering the complexities of the exposition of the plays, so that a reader uninitiated in Ibsen could make sense of them. He managed to draw comparisons and illustrations from the whole tradition of the 19th-century European literature and thought. In terms of contents, Shaw places Ibsen with Shelley, Dickens, Butler, and Darwin. That Shaw was primarily concerned with the way the public reacts to Ibsen can be exemplified by the analysis of Ghosts, consisting of the enumeration of newspapers reviews, which enables the reader to detect the artistic perception of the British press with respect to Ibsen. 
In spite of our latent pesismism towards Shaw's Ibsen criticism, there is a second important success in The Quintessence when he talks, though not explicitly, about three of the crucial principles of posterior Ibsen criticism. In his monumental work on Shaw and Ibsen, Wisenthal cites them saying that: “one must know all Ibsen's work to understand any of it; one must study the plays chronologically in order to grasp all the relationships between them; one must recognize a continuous theme running through all the plays" (Wisenthal 38). Obviously, these principles are open to question, though it is not the purpose of this essay to get into them. What is clear, is that, to a smaller extent, Shaw's criticism is pioneering the 20th-century view of the Scandinavian playwright.

So far we have only analyzed Shaw's first criticism, that is the first edition of The Quintessence published in 1890 . The fact that the British critic and playwright brought his essay up to date twenty years later indicates two shifts in Shaw's attitude: first, a change in his critical emphasis, which reveals a new approach to Ibsen. Second, and more important, is that Shaw, throughout these twenty years, had seen how Ibsen had been accepted as a classic, along with his own consolidation as a well known playwright. By 1913 Ibsen was no longer controversial and Shaw was a famous and original writer, having written most of the plays for which he is now known.

As mentioned above, in his dramatic criticism, Shaw writes a history of audience relations. By 1913 it was taking place a re-evaluation of Ibsen by his audience. In the first place, the audience for Ibsen was no longer primarily composed of readers, for the modern stage drama had won a place on the stage. Shaw recognized this development and, in his own discussion of Ibsen's last four plays, he distinguished clearly between the dramatic form of the plays and the novelistic summaries which he still provided with the purpose of making it easier to follow the play in performance.

Secondly, the audience was far more sophisticated and had outgrown Ibsen in some respects. Shaw's goal was no longer polemic, since the battle had been won. At this point, Shaw was able to look back dispassionately and assign Ibsen his place in the evolution of ideas and form in modern drama. From this distant point of view, Shaw was also able to develop himself as a playwright supported by Ibsen's constant growing. To confirm this, and to place this retrospective evaluation of Ibsen's level in drama, Shaw realized that he himself, along with Ibsen's other followers, may have been responsible for creating a false picture of Ibsen. He states in the second edition of The Quintessence:

When an author's work produce violent controversy, and are new, people are apt to read them with that sort of seriousness which is very appropriately called deadly ... I remember a performance of The Wild Duck, at which the late Clement Scott pointed out triumphantly that the play was so absurd that even the champions of Ibsen could not help laughing at it. It had not occurred to him that Ibsen could laugh like other man. (Quintessence 185)

In the chapter "The Technical Novelty of Ibsen's Plays," Shaw discusses not only the impact of Ibsen on younger dramatists, but also upon himself. Shaw goes as far as issuing a general manifesto for the new drama. In many ways this program goes beyond Ibsen's own work. As a matter of fact, it is the main cause of the accusations that The 
Quintessence is about Shaw, not Ibsen. Although we accept that Shaw deviates from Ibsen in this point, it has to be emphasized that such digression was caused by Ibsen's influences on Shaw, and more specifically, by the overwhelming impact of the former over the latter.

Another proof of this incessant admiration that Shaw professed for the Scandinavian can be grasped when Shaw affirms that:

Formerly you had in what was called a well made play: an exposition in the first act, a situation in the second, an unravelling in the third. Now you have exposition, situation and discussion; and the discussion is the test of the playwright... The discussion conquered Europe in Ibsen's Doll's House; and now, the serious playwright recognizes in the discussion not only the main test of his highest powers, but also the real centre of his play's interest. (Quintessence 187-88)

Shaw is supporting the thesis that Ibsen prepared the way for later developments in which he had no part, although it is curious to note that he never mentions Ibsen explicitly along The Quintessence to this respect. Because of Ibsen, it is now possible for a dramatist like Shaw to write plays that begin with discussion rather than end with it; or even, that are all discussion.

If we are to understand The Quintessence we must recognize that Shaw is telling us how Ibsen conditioned audiences for developments that go beyond his own works and how Ibsen influenced the whole new school of dramatists. But it must be also recognized that The Quintessence does not tell us a great deal about the plays as plays, but that it is full of information about Ibsen in relation to British public opinion and to the new drama in England. As a critical examination of Ibsen's plays for one who already knows them, the book is hardly satisfying. His treatment of the characters is inadequate; Ibsen's power lies in his creation of characters and in his powerful constructions. In The Quintessence, Shaw seems to fail to see those characteristics.

Nevertheless, The Quintessence of Ibsenism is not such an awful misinterpretation as has been said by the critics. It has its value as a general introduction to Ibsen and as a study in the relation between Ibsen and the English theater. Furthermore, Shaw must be forgiven, since he did not stop writing about Ibsen. Both Our Theatres of the Nineties and the Prefaces make up for the qualities that were lacking in The Quintessence.

In Our Theatres of the Nineties Shaw writes with the authority of a playwright, as well as with the experience of a dramatic critic. Meanwhile, The Quintessence gives us an abstract picture of Ibsen's plays and Our Theatres creates a lively and detailed impression of the characters and dialogues. The already discussed controversy set by Ibsenism is still fresh in Shaw's mind, but now the reason prevails, and he feels free to correct the exaggerations of his earlier fanatism, paying more attention to the technical side of the drama.

It is at this stage that Shaw points out what for him is the most distinctive feature of all of Ibsen's later plays: they all begin with a catastrophe. With this device, Ibsen avoids wasting an act or two on preparations, and can start his plays at an advanced state of action. Shaw believes that this technique comes from Ibsen's new subject exploration: marriage. According to this, his dramas open where the romantic plays end. He wrote in 
Our Theatres: "The Ibsen drama is preeminently the drama of marriage. That is just where an ordinary play leaves off, and just where an Ibsen play begins" (Our Theatres 84). Shaw's appreciation is totally adequate, but he fails to emphasize enough the role of the past in Ibsen.

Before continuing with the analysis of Shaw's criticism, let me make an aside, and discuss this different dramatic conception of time that Shaw and Ibsen had, which I believe essential to the comprehension of both playwrights' works. Shaw observed in 1893 that there was no trace in Widowers' Houses of Ibsen's peculiar retrospective method. By this technique, Ibsen's plays were made to turn on events supposed to have happened before the rise of the curtain. This lack applies to most of Shaw's plays, though, of course, some references to the past can be found in Mrs. Warren's Profession, Missalliance or Heartbreak House. But in these examples, the past has little or no pressure on the present. For instance, Mrs. Warren's revelations about her past do not prevent Vivie from liberting herself from it. Also, in Heartbreak House Boss Mangan's confession about his exploitation of Mazzini Dunn, a past event which would have produced a chain of tragic results in an Ibsen play, has no effect whatsoever on the present in Shaw's.

During a play of Shaw's, we do not keep asking ourselves, as we do during an Ibsen play, "what is behind all this" (Ibsen 369), as Mrs. Solness says in the second act of The Master Builder. Whereas Ibsen's plays look to the past, Shaw's look to the future; and while Ibsen is highly sensitive to the pressure that the past has on the present, Shaw sees the present in relation to what kind of future it is leading towards. In other words, Ibsen's plays are sequels; Shaw's prologues.

In The Quintessence Shaw talks about Ibsen's characters as living human beings. In his posterior criticism, he took the opposite position, stressing the strength of Ibsen's personages. In many of the Saturday Reviews he devoted a lot of attention to analyzing the actor's interpretation and to comparing these interpretations with Ibsen's conceptions of the characters.

Another spectacular shift that occurred in Shaw's Our Theatres is the evident sensitivity shown towards Ibsen's poetry. In a highly poetic review of a production of $P e e r$ Gynt in 1896 he wrote:

Peer Gynt will finally smash anti-ibsenism in Europe, because Peer is everybody's hero. He has the same effect on the imagination that Hamlet, Faust and Mozart's Don Juan have had. Thousands of people who will never read another line of Ibsen will read Peer Gynt again and again; and millions will be concious of him as a part of the poetic currency of the world without reading him at all. Nobody who is susceptible to legendary poetry can scape the spell if he once opens the book. (Our Theatres 248-49)

To summarize this second stage of Shaw's criticism, Our Theatres orientates its critical center around the play itself. That is, around the organization of its elements, and its artistic effect. But, at the same time, Shaw continues his main idea developed in The Quintessence, the effect of Ibsen on the audience. In this respect, Shaw drew a very important conclusion, that the immediate success or failure of Ibsen was not too important; what mattered was his ultimate influence on the public taste. 
The final stage of Shaw's Ibsen criticism is found in the Prefaces, which include prefaces to his own plays, novels, and essays, as well as other authors'. The comments on Ibsen which we find here are less extensive than those in the reviews. Very often, he mentions Ibsen's name only in passing or uses it in order to illustrate a point. However, there are enough references throughout the Prefaces to realize of his continuing interest in Ibsen and to formulate Shaw's final opinion of a writer whom he had studied for many years. The Prefaces date from 1893 to 1933; therefore, they can be considered, in general, as the final word of Shaw's Ibsen criticism.

First of all, in the Prefaces, there is a new relationship between the critic and the author criticized; Shaw is now a world famous dramatist and looks back into the 19thcentury at lbsen, whom he admired and still admires, but with some reservations. And these reservations become the substance of his final estimate of Ibsen.

Shaw now, considers himself the master of modern drama, and obviously, where these theories come into conflict with Ibsen, he is openly critical. In the Prefaces, Ibsen is seen as a necessary stage in the evolution of the drama. But his period is now history, and though Shaw still recognizes Ibsen's genius, he shows a sense of superiority due to the progress made since the 19th-century. It is relatively easy to understand why Shaw would be concerned to diassociate himself from a more famous author whose cause he had argued so vehemently. When the critics accused him of being a mere imitator of Ibsen, a supposition which he had fostered, it is logical that he would gradually attempt to set himself in a position of equality or even superiority respect to the master.

He was called "the London Ibsen" by the reviewers of his first play, Widowers' Houses. But as early as 1893, Shaw was trying to deny that direct influence in one of his prefaces: "Now the first two acts of Widowers' Houses were written in 1885 when I knew nothing about Ibsen. There is not an idea in the play that cannot be more easily referred to half a dozen English writers than to Ibsen" (Prefaces 672). He tries to establish himself in the English tradition, condemning any corruption by foreign ideas. It is curious that he ascribes himself with the novelists, such as Spencer, George Eliot and Charles Lever.

In the preface to Three Plays by Brieux Shaw explains how he came under the influence of the naturalistic movement with which Ibsen was sometimes associated because of Ghosts and how he rejected it later. First, Shaw regarded this movement as a necessary reaction against some taboos, especially the sexual. But at the same time, he recognized that such approach was in spirit anti-artistic. At this point, Shaw is reaffirming the traditional English belief that literature should, in general terms, be pleasant and contain positive values, such as Shaw's own Life Force.

In The Quintessence Shaw had proclaimed the originality of Ibsen's technique. In the Prefaces he points out a number of residues of tricks and devices that still remains in Ibsen's work. Since Shaw excludes the subjects of naturalism for being unnatural, the technique of the drama should be modified in accordance with his new concept of life. This consists of the postulation of the everyday, the average, and the correct view of human nature. That is why he says in another preface that:

The tragedy of Hedda in real life is not that she commits suicide but that she continues to live. The tragedy of modern life is that nothing happens and that the resultant dullness 
does not kill. In Ibsen's works we find the old traditions and the new conditions struggling in the same play ... Not only in the tradition of the catastrophe unsuitable to modern studies of life: the tradition of an ending, happy or the reverse, is equally unworkable. (Prefaces 199-200)

In accordance to the comparison of the three stages of Shaw's Ibsen criticism, it is easy to come to the conclusion of thinking of the British playwright in a continuous evolutioning process. Shaw had for Ibsen a lifelong admiration; his attitude was never fixed and dogmatic, but always dynamic and changing. As dynamic and changing as his own dramatic work, which found its turning point in Man and Superman, it can be affirmed that Shaw's Ibsen criticism is a faithful reflection of his dramatic plays with a quintessence, a ninety period, and a final preface stage.

\section{Works Cited}

Franc, Miriam A. Ibsen in England. Boston, 1919.

Ibsen, Henrik. Collected Works of Ibsen. New York: Greystone Press, 1957.

May, Keith. Ibsen and Shaw. London: Macmillan, 1985.

McKee, Irving. "Bernard Shaw's Beginnings on the London Stage." Publications of the Modern Language Association of America 54 (1939): 212-19.

Shaw, Bernard. Our Theatres in the Nineties. London, 1932.

The Quintessence of Ibsenism: Now Completed to the Death of Ibsen. London: Constable, 1913.

. Plays: Man and Superman, Arms and the Man, Mrs. Warren's Profession, and Candida. New York: New American Library, 1960. . Prefaces. London, 1934.

Wellwarth, George. "Mrs. Warren Comes to America: Or the Blue-Noses, the Politicians, and the Procurers." The Shaw Review May 1959: 123-32.

Wisenthal, J. L. Bernard Shaw's The Quintessence of Ibsenism and Related Writings. Toronto: University of Toronto Press, 1979. 